\title{
LANDSCAPES OF THE TENIZ-KORGALZHYN DEPRESSION IN THE REPUBLIC OF KAZAKHSTAN: EVALUATION OF ECOSYSTEM FUNCTIONS AND OPPORTUNITIES FOR TOURISM
}

\author{
Yerzhan N. SAGATBAYEV ${ }^{*}$ \\ L. N. Gumilyev Eurasian National University, Department of Physical and Economical \\ Geography, 2 Mirzoyanst, 0100o8, Nur-Sultan Kazakhstan, e-mail: sagatbaeve@mail.ru

\section{Sergey V. PASHKOV} \\ M. Kozybayev North Kazakhstan State University, Department of Geography and Ecology, \\ Pushkin St. 86, 1500oo, Petropavlovsk, Republic of Kazakhstann, e-mail: sergp2001@mail.ru
}

\begin{abstract}
Alexander N. DUNETS
Altai State University, Department of Economic Geography and Cartography, Pr. Lenina 61a, 656049 Barnaul, Russia, e-mail: dunets@mail.ru
\end{abstract}

\section{Ordinbek B. MAZBAYEV}

L. N. Gumilyev Eurasian National University, Department of Physical and Economical Geography, 2 Mirzoyanst, 010008, Nur-Sultan Kazakhstan, e-mail:ordenbek@mail.ru

\begin{abstract}
Citation: Sagatbayev, Y.N., Pashkov, S.V., Dunets, A.N. \& Mazbayev, O.B. (2019). LANDSCAPES OF THE TENIZ-KORGALZHYN DEPRESSION: EVALUATION OF ECOSYSTEM FUNCTIONS AND OPPORTUNITIES FOR TOURISM. GeoJournal of Tourism and Geosites, 26(3), 1046-1056. https://doi.org/10.30892/gtg.26328-416

Abstract: Based on the concept of total environmental value, it is estimated the total economic value of the geosystem functions of the wetlands of specially protected natural territories of the Teniz-Korgalzhyndepression A comprehensive cost accounting of the indirect functions of the landscape has been carried out: environment -regulating, environment-forming, ethical, aesthetic and others - which are usually not taken into account in the economy, in contrast to the market-based approach to assessing natural resources. The development of tourism in the region is considered, especially of the ecotourism, which have a good perspectives.
\end{abstract}

Key words: landscapes, protected natural areas, wetlands, geosystem functions, ecotourism, Teniz-Korgalzhyn depression.

\section{INTRODUCTION}

One of the problems of rational use of renewable natural resources is associated with the insufficient development of an economic assessment of the indirect ecosystem

\footnotetext{
* Corresponding author
} 
functions of landscapes, which leads to their "non-competitiveness" in comparison with traditional (resource) ways of economic development. This largely explains the relevance of the selected research topic. Evaluation of the ecosystem functions of landscapes is a multicomponent task, due to their complex structural and functional organization. To determine the significance of landscapes, an assessment of three main functions is necessary: resource-providing, environment-regulating and aesthetic.

Teniz-Korgalzhyn depression is located in the Akmola and Karaganda regions of central Kazakhstan, South-West from the capital city Nur-Sultan. Total area of the depression is $32662 \mathrm{~km} 2$, from which arr. $2600 \mathrm{~km}^{2}$ are lakes and wetlands (Figure 1).

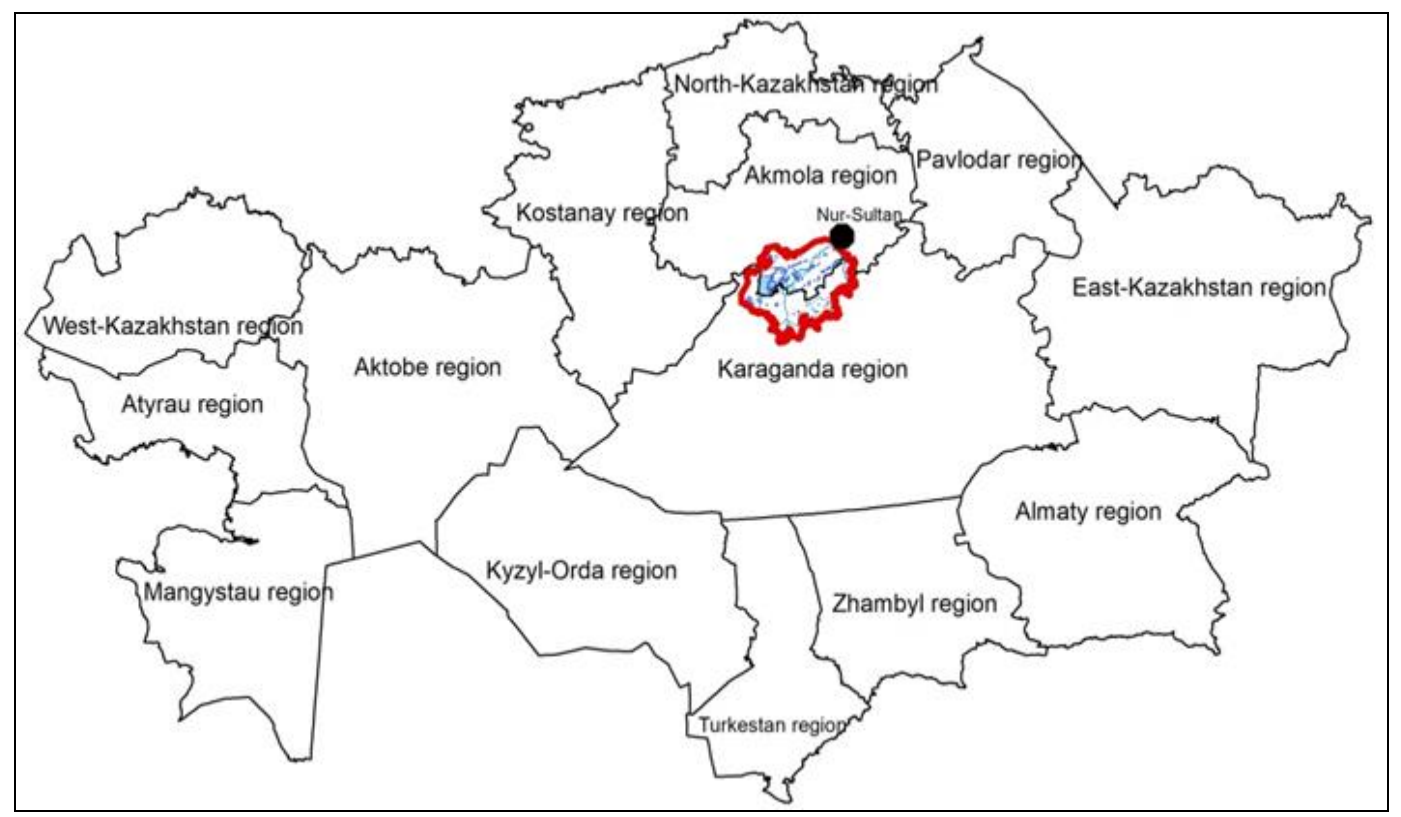

Figure 1. Geographical position of the Teniz-Korgalzhyn depression

This area forms an unique ecosystem for Kazakhstan, considering the landscape, wetlands and specific flora and fauna. For this reason in 1968 here was established the Korgalzhyn State Reserve as special natural protected area. In 1974, the Teniz-Korgalzhyn wetlands were included in the Ramsar list. In 2002, Lake Teniz, the first and so far the only one in Kazakhstan, was included in the Living Lakes international network, which includes the most unique lakes in the world. At present, the territory of the Korgalzhyn State Reserve has been proposed for inclusion in the UNESCO list of natural heritage, including areas of particular importance for the conservation of wetland birds. The landscapes of the Teniz-Korgalzhyn depression are largely represented by wetlands. They act as a regulator of many processes: accumulation and storage of fresh water, water filtration, absorption from the atmosphere and carbon accumulation, oxygen circulation to the atmosphere, regulation of surface and underground runoff, stabilization of groundwater levels, participation in the formation of climatic conditions, containment of erosion processes, maintenance and conservation of biological diversity. In addition, they play an important role in the conservation and development of traditional natural resource management. Wetland landscapes provide many types of non-market and market services, and their total value exceeds the value of economic transformation. 
There are numerous examples that show how much the economic value of natural landscapes exceeds the value of the transformed ones. This can include the Tourism, Fishing, Bird watching, Pastures, Agriculture etc (Barbier et al., 1997; Brander et al., 2003; Ilieş \& Wendt, 2015; Ilieş et al., 2018; Gozner et al., 2017; Gozner, 2010).

\section{OBJECTS AND METHODS OF RESEARCH}

The following writings by Preobrazhenskiy, 1975; Mukhina, 1973; Kotlyarov, 1978; Chizhova, 2011) were used as a guide for this research work. Mironenko N. S. and Bochvarova M. (1986) justified the possibility of recreational systems as well as the diversity of evaluation methods. Therefore we represent the research area landscapes as a system. Good research work was done on evaluation of North Kazakhstan landscapes for recreation (Mazhitova et al., 2018). The article used materials on the recreational assessment of lake systems in Northern Kazakhstan (Nazarova et al., 2019).

Assessment of the ecosystem functions of landscapes was carried out within the largest wetlands in the specially protected natural areas of the Teniz-Korgalzhinsk depression: the Tengiz-Korgalzhinsk lake system in Central Kazakhstan (Figure 2). The work is based on collected data, expert assessments, materials of the nature records of protected natural areas and field observations of the authors.

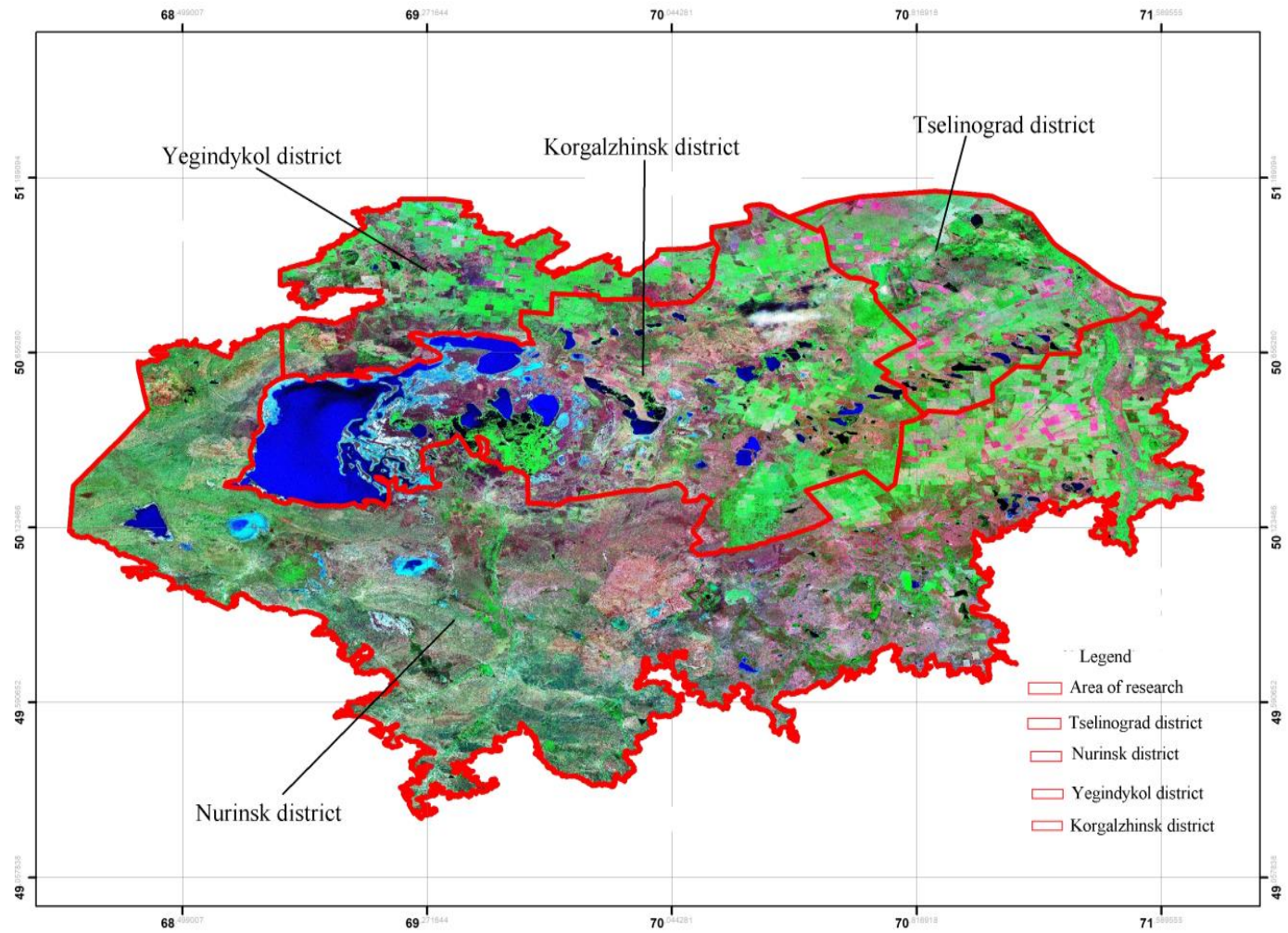

Figure 2. Satellite image. Teniz-Korgalzhyn depression

The understanding of landscapes' ecosystem functions is based on the perception of the territory as a complex active self-organizing system. It is at the same time forms a part of more large-scale system "nature - society". The analysis of inter-relations in the system 
Landscapes of the Teniz-Korgalzhyn Depression:

Evaluation of Ecosystem Functions and Opportunities for Tourism

allows to define the main ecosystem functions. The calculations are based on the concept of the total economic value of natural resources (Millennium of geo system Assessment, 2005). Today it is the most comprehensive approach to the assessment of natural resources and services (Table 1). The methodology takes into account several parameters that cover the direct cost of use, the indirect cost of use and the cost of non-use.

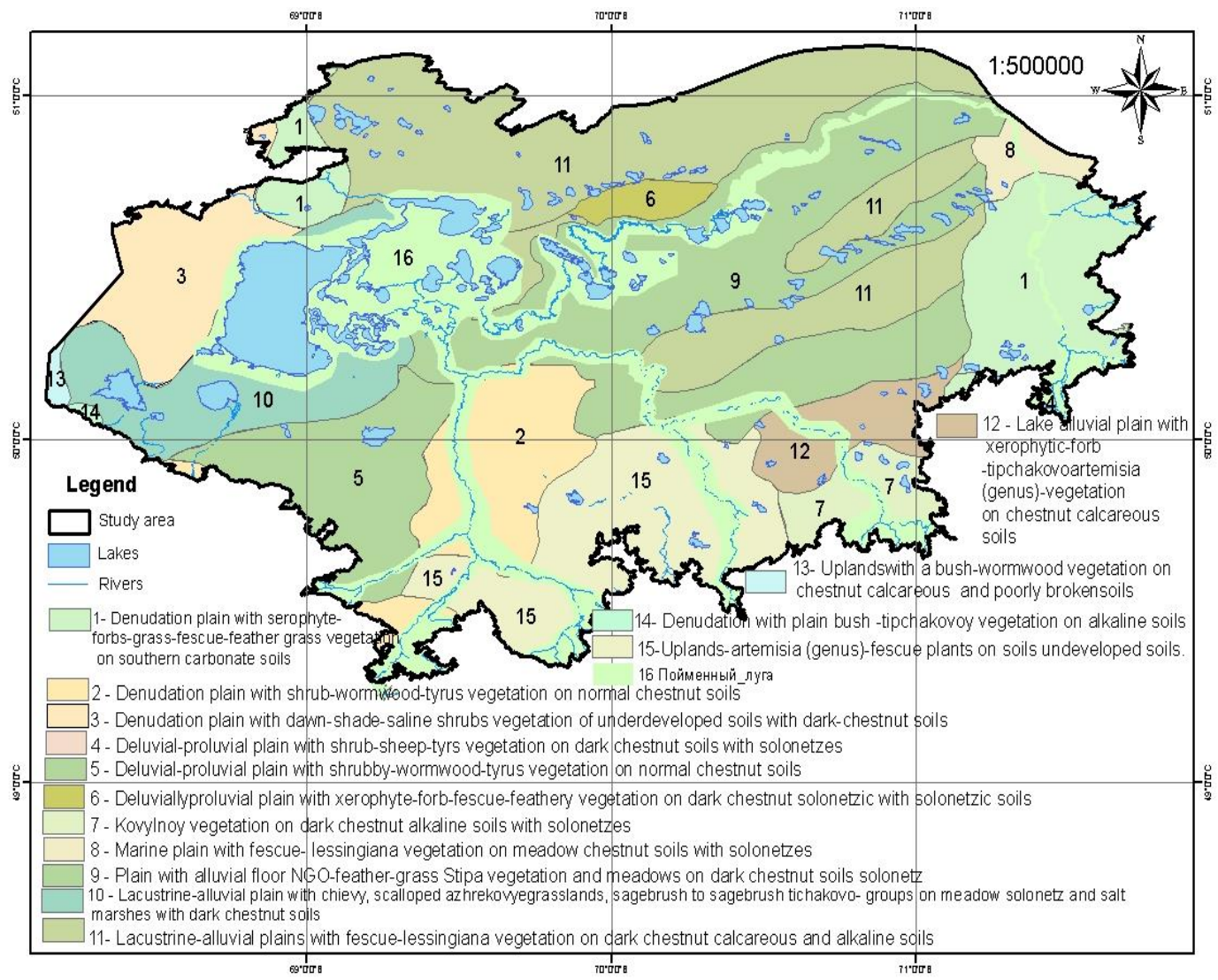

Figure 3. Natural landscapes of the Teniz-Korgalzhyn depression

(Atlas of Wetlands of Kazakhstan.., 2009)

Table 1. Methodology for the implementation of economic valuation of natural resources and ecosystem services, provided in Kazakhstan wetlands

\begin{tabular}{|l|l|}
\hline \multicolumn{1}{|c|}{$\begin{array}{c}\text { Natural resources and } \\
\text { geosystemservices }\end{array}$} & \multicolumn{1}{c|}{ Used methods of economic valuation } \\
\hline Biodiversity & Normative method of compensation for damage \\
\hline Grasslandandpasture, tilled area & Marketpricemethod \\
\hline Filtration (water treatment) capacity of lakes & ReplacementCostMethod \\
\hline Carbonsequestration & Volumetricconversionmethod \\
\hline Tourismandrecreation & $\begin{array}{l}\text { The method of market prices, the method of } \\
\text { transportation costs }\end{array}$ \\
\hline
\end{tabular}

General economic assessment. Assessment of the total economic value of wetland landscape services was carried out on the basis of the calculation of the following 
indicators: economic assessment of natural resources, assessment of tourist and recreational potential, assessment of agricultural land, assessment of the filtering ability of wetlands, assessment of carbon dioxide binding to forest and meadow vegetation. A general economic assessment of natural resources, namely, the assessment of key animal species, was carried out using standard methods (Bobylyov, 2001). The calculations were carried out according to the nature resources records and annual reports of the Forestry and Hunting Committee of the Ministry of Agriculture of the Republic of Kazakhstan.

\section{RESEARCH RESULTS}

\section{Economic assessment of wildlife}

When calculating the economic value of biological resources, a tax-based method of economic assessment was used to calculate the amount of recovery for damage caused by illegal extraction or destruction of wildlife. The sizes of taxes are established at the national level by the Decree of the Government of the Republic of Kazakhstan No. 1140 dated September 4, 2001 "The sizes of compensation for harm caused by violation of the legislation on the protection, reproduction and use of wildlife." Valuation was carried out among hunting and commercial species of animals (birds and animals) that are at risk of extermination. The calculation is given by the formula (Bobylyov, 2001):

$$
\mathrm{E}=\mathrm{n} \cdot \mathrm{Y},
$$

where: $E$-is the economic value of a certain animal species in monetary terms, $n$ - is the number of individuals of this species recorded in the wetland, $Y$ - is the size of the fee for damage to the biological species.

The main hunting and commercial species of mammals on the territory of the studied wetlands are wild boar, fox, hares, marmots, muskrats, saigaks, corsacs, etc. It is these species that are more susceptible to intensive extermination during unorganized hunting, so now there are at risk: saigaks, moose, roe deer, gazelles and others.

The economic value of each species was calculated according to the key hunting and commercial species of mammals and birds for each wetland (The Most Important Wetlands, 2002). The most numerous species (ducks and geese) that were not included in the list of rare and endangered species were taken to calculate the valuation of hunting and commercial bird species. The calculations were carried out according to the same formula of the total economic value, but instead of the fees for causing harm, were taken the rates of payment for one hunting and commercial individual, which are established by the tax code of the Republic of Kazakhstan within the limit on the extraction of these species. Tax rates vary depending on the type of hunt: pay rates among amateur hunters are two times higher than those of hunters. The total cost of animals and birds in the territory of the Kazakhstan wetland was calculated according to the approximate cost of the main species of animals and birds (Table 2).

Table 2. The total value of animals and birds of Kazakhstan wetlands (according to the Forestry and Hunting Committee of the Ministry of Agriculture of the Republic of Kazakhstan and to the Decree of the Government of the Republic of Kazakhstan № 1140 fromo 4.09.2001)

\begin{tabular}{|c|c|c|c|c|}
\hline $\begin{array}{c}\text { Name of the } \\
\text { object }\end{array}$ & $\begin{array}{c}\text { Value of } \\
\text { commercial and } \\
\text { rare species of } \\
\text { mammals, \$ CWA* }\end{array}$ & $\begin{array}{c}\text { Value of } \\
\text { commercial and } \\
\text { rare species of } \\
\text { birds, \$ USA }\end{array}$ & $\begin{array}{c}\text { Value of main } \\
\text { commercial- } \\
\text { hunting species of } \\
\text { birds, \$ USA }\end{array}$ & $\begin{array}{c}\text { Total } \\
\text { cost, } \\
\mathbf{\$} \text { USA }\end{array}$ \\
\hline $\begin{array}{c}\text { Tengiz-Korgalzhyn } \\
\text { system of lakes }\end{array}$ & $\mathbf{1 . 0 2 2 . 7 6 5}$ & 78.590 .703 & 170.795 & 79.784 .263 \\
\hline
\end{tabular}




\section{Assessment of tourist and recreational potential}

The cost of direct use of the territory for tourism was calculated by assessing the annual income received from the organization of excursions, exhibitions and other events in the buffer zones of Korgalzhyn Nature Reserve (Table 3). The total cost of the services provided includes the transportation costs of tourists, the provision of viewing platforms, the provision of bivouac glades, a visit to the Museum of Nature, the provision of catering facilities, and housing costs. It is worth noting that more than $80-85 \%$ of the costs are for housing costs and only 3-4\% are for transport (Conservation Economy., 2002). Income data was taken from the official development programs of Akmola Oblast, oblasts for 2011-2018.

Table 3. Assessment of recreational potential of the main wetlands sites, which host tourists (according to the data of the District Development Programs of 2011-2018)

\begin{tabular}{|l|l|l|c|c|}
\hline \multicolumn{1}{|c|}{$\begin{array}{c}\text { Name of the } \\
\text { object }\end{array}$} & \multicolumn{1}{|c|}{ Infrastructure } & $\begin{array}{c}\text { Transport } \\
\text { accessibility to major } \\
\text { administrative centers }\end{array}$ & $\begin{array}{c}\text { Average } \\
\text { tourist flow, } \\
\text { persons/year }\end{array}$ & $\begin{array}{c}\text { Cost, } \$ \\
\text { USA }\end{array}$ \\
\hline $\begin{array}{l}\text { Korgalzhyn } \\
\text { Nature Reserve } \\
\text { (Korgalzhyn } \\
\text { village) }\end{array}$ & $\begin{array}{l}\text { Six guest houses, three hotels, } \\
\text { five cafes, a home kitchen, two } \\
\text { restaurants, a nature museum, } \\
\text { hunting grounds, etc. }\end{array}$ & $\begin{array}{l}\text { 130 km to } \\
\text { Nur-Sultan city, } 2 \\
\text { hours of driving }\end{array}$ & 4500 & 766700 \\
\hline
\end{tabular}

As can be seen from table 3, Korgalzhyn Nature Reserve received anaverage of 4500 visitors yearly, which contribute to the income from the tourism activities. Considering that total visitors in the region of Teniz-Korgalzhyn depression was more than 28 thousand people in 2018, there is a potential for the growth of the tourism income. Therefore, we can conclude that most tourists do not use the services of tourist organizations and, most likely, unorganized tourism predominates in this territory. The main type of tourism in the protected areas is associated with the scientific and educational interest of visitors. Visitors are accepted by the administrative center of the reserve in the Korgalzhyn village and the ecotourism activities are encouraged. The greatest development of tourism is promoted by the Korgalzhyn district, which is due not only to the rich tourist and recreational potential, but also to the significant funding coming from Nur-Sultan.

\section{Economic valuation of natural resources of agricultural land}

Agricultural land of the studied region consist of pastures, hayfields and tilled fields. Pastures prevail within all wetlands under consideration. They occupy from $50 \%$ in the Tengiz-Korgalzhyn system of lakes to the $95 \%$ of the whole depression. Harvesting hay and green fodder is carried out by local residents who have livestock in their personal households. The maximum share of tilled fields was recorded in the Korgalzhyn district up to $47 \%$, for the rest of the districts it ranges from $14 \%$ to $20 \%$. Hayfields occupy small areas from $3 \%$ to $6 \%$ (Table 4 ).

Table 4. The structure of agricultural land on Kazakhstan wetlands (according to the data of the District Development Programs of 2011-2018, and to the Ministry of Agriculture of the Republic of Kazakhstan)

\begin{tabular}{|c|c|c|c|c|c|c|c|}
\hline \multirow{2}{*}{$\begin{array}{c}\text { Type of agricultural } \\
\text { lands }\end{array}$} & \multicolumn{2}{|c|}{ Haylands } & \multicolumn{2}{|c|}{ Tilled fields land } & \multicolumn{2}{c|}{ Tilled fields } & Total agricultural \\
\cline { 2 - 7 } & ha & $\%$ & ha & $\%$ & ha & $\%$ & lands, ha \\
\hline $\begin{array}{c}\text { Tengiz-Korgalzhynsystem } \\
\text { of lakes }\end{array}$ & 16.863 & 3.1 & 268.719 & 49.4 & 258.384 & 47.5 & 543.966 \\
\hline
\end{tabular}

Tengiz-Korgalzhyndepression is characterized by the development of agricultural production. The main direction of agriculture is the production of grain. Unlike the Tengiz-Korgalzhynagricultural system, the structure of farmland in the Nura district is 
dominated by pastures. The leading role in the economy of the Nura district belongs to the production of agricultural products. It is worth noting that in recent years, the coal industry has begun to develop actively. Economic valuation of agricultural land, namely pastures, grasslands and tilled fields, was carried out on the basis of the market valuation method. The assessment is based on indicators of the yield of farmland types and market prices of their main products (Table 5). Filtration ability of wetlands. One of the most important regulatory functions of wetlands is the accumulation, storage and purification of fresh water. Riding bogs and lakes are highly effective in wastewater treatment. The Teniz-Korgalzhyn system of lakes includes several tens of small and 2 large salt lakes Tengiz and Korgalzhyn, the water volumes of which are 955 million $\mathrm{m}^{3}$ and 386 million $\mathrm{m}^{3}$, accordingly. The volume of fresh lakes is much smaller - 511 million $\mathrm{m}^{3}$ (Globally significant, 2007). Fresh lakes of the Teniz-Korgalzhyn depression are represented by lakes of two groups: Besshalkar and Uzynkol-Zharlykol (Bragin et al., 2002).

The most desalinated body of water in the Alakol-Sasykkol system is Sasykkollake. It is located in the northwestern part of the Alakol depression and has the largest volume of water among the studied objects -2.43 billion $\mathrm{m}^{3}$. More than 45 thousand ha of bogs adjoin the lake (Wildlife reserves, 2006). The Ural River is the only major source of fresh water in the Ural Delta system and the adjacent coast of the Caspian Sea. Annually, it brings in more than $8 \mathrm{~km}^{3} / \mathrm{s}$ of fresh water (Wildlife reserves, 2006). This is the second largest freshwater runoff after the Volga river brought to the Caspian Sea. The basin of the Syr-Darya River, the largest of the rivers flowing into the Aral Sea and feeding it, has been used since ancient times as a region of irrigated agriculture. Intensive water intake from the river for irrigation led to a decrease in the annual flow coming to the Aral Sea, which led to the Aral Sea disaster. Until the 1950s, the annual flow of the river was $22-45 \mathrm{~km}^{3} /$ $\mathrm{s}$, but since 1974, the flow has decreased to $1.3 \mathrm{~km}^{3} / \mathrm{s}$ (Biodiversity, 2012). Currently, the annual freshwater flow in the Syr Darya is about $6 \mathrm{~km}^{3} / \mathrm{s}$.

Table 5. Economic value of hay on Kazakhstan wetlands (according to the data of the District Development Programs of 2011-2018, and to the Ministry of Agriculture of the Republic of Kazakhstan)

\begin{tabular}{|c|c|c|c|c|c|c|c|}
\hline $\begin{array}{c}\text { Name of } \\
\text { the object }\end{array}$ & $\begin{array}{c}\text { Hayland, } \\
\text { ha }\end{array}$ & $\begin{array}{c}\text { Cost of } \\
\text { hay, } \\
\text { thousand } \\
\text { \$ USA }\end{array}$ & $\begin{array}{c}\text { Grazing } \\
\text { land, } \\
\text { ha }\end{array}$ & $\begin{array}{c}\text { Cost of } \\
\text { solage, } \\
\text { thousand } \\
\text { \$ USA }\end{array}$ & $\begin{array}{c}\text { Tilled } \\
\text { land, } \\
\text { ha }\end{array}$ & $\begin{array}{c}\text { Wheatcost, } \\
\text { thousand } \\
\text { \$ USA }\end{array}$ & $\begin{array}{c}\text { Total cost of } \\
\text { agricultural } \\
\text { lands, thousand } \\
\text { \$ USA }\end{array}$ \\
\hline $\begin{array}{c}\text { Tengiz- } \\
\text { Korgalzhinsksystem } \\
\text { of lakes }\end{array}$ & 16863 & 139.9 & 268719 & 5229.3 & 258384 & 58136.4 & 63505.6 \\
\hline
\end{tabular}

The cost of indirect use of lakes and bogs was estimated by their filtering ability in comparison with the filtering ability of an industrial treatment plant (ITP), the transmittance of which is $1500 \mathrm{~m}^{3} /$ day, the average price reaches $\$ 50$ thousand, and the service life is not less than 50 years. In the course of work, the average price for $1 \mathrm{~m}^{3}$ of fresh water was calculated, which amounted to $\$$ 0.002. The calculations were performed as follows: the number of days in a year was multiplied by the transmittance of the ITP in order to obtain the amount of fresh water that is filtered by one ITP for its entire operational period (on average 50 years). Further, in order to obtain the cost of $1 \mathrm{~m}^{3}$ of purified water, the price of ITP was divided by the amount of fresh water that ITP purifies in 50 years. As a result, the total cost of water treatment services for wetlands amounted to more than $\$ 6$ million (Table 6).

The binding of carbon dioxide. Forest and meadow vegetation, confined to wetland ecosystems, in the process of photosynthesis absorbs carbon dioxide and releases oxygen, 
thereby purifying the atmospheric air. Such benefits provided by the ecosystem can be used in calculating the indirect value of wetlands. Their biological productivity per year was taken based on the calculation of carbon deposition values by forest and meadow communities. Forest vegetation in the studied areas is represented by coniferous and small-leaved forests, broad-leaved and tugai forests stand out in the eastern mountainous part. Meadow vegetation is represented by different types of meadows. These include real, marshy, steppe and halophytic meadows. Meadows are confined to special, additionally moistened habitats: floodplains of rivers, lakes, depressions, dry beds, groundwater outlets, etc. According to the Forestry and Hunting Committee of the Ministry of Agriculture of the Republic of Kazakhstan, the productivity of forests in Kazakhstan, which are combined with wetlands, is quite low - about $0.7 \mathrm{~m}^{3}$ per hectare.

Table 6. Economic cost of the filtration capacity of Kazakhstan wetlands (according to the data of the District Development Programs of 2011-2018)

\begin{tabular}{|c|c|c|c|c|c|}
\hline & $\begin{array}{c}\text { Naurzum } \\
\text { system of } \\
\text { lakes }\end{array}$ & $\begin{array}{c}\text { Delta of Ural river } \\
\text { and the adjacent } \\
\text { coast of the } \\
\text { Caspian Sea }\end{array}$ & $\begin{array}{c}\text { Teniz- } \\
\text { Korgalzhyn } \\
\text { system of } \\
\text { lakes }\end{array}$ & $\begin{array}{c}\text { Alakol- } \\
\text { Sasykkol } \\
\text { system } \\
\text { of lakes }\end{array}$ & $\begin{array}{c}\text { Small Aral } \\
\text { Sea and } \\
\text { Syr-Darya } \\
\text { river`s delta }\end{array}$ \\
\hline $\begin{array}{c}\text { Volume of fresh } \\
\text { water, m }{ }^{3}\end{array}$ & $93.8 \mathrm{mln}$. & $8000^{* * *}$ & $511 \mathrm{mln}$. & $\begin{array}{c}2.43 \\
\text { billion }\end{array}$ & $6000^{* * *}$ \\
\hline $\begin{array}{c}\text { Cost of wetland filtration } \\
\text { capacity, \$ USA }\end{array}$ & 187600 & 16 & 1022000 & 4860000 & 12 \\
\hline Total & \multicolumn{7}{|c|}{$6 \mathrm{mln} .72$ thousand $622 \$$} \\
\hline
\end{tabular}

Notes to table $6:^{* * *}$ - the annual flow of freshwater $(\mathrm{m} 3 / \mathrm{s})$, coming into the reservoirs.

The value of forest productivity is necessary for calculating the amount of carbon dioxide absorbed from the atmosphere per 1 hectare of forest land. This value was multiplied by a coefficient of 0.63 (volume conversion coefficient, the choice of which depends on the natural zone, breed and age of the plant; (Bobylyov, 1999), necessary to convert the volume of productivity to weight, then the resulting value is multiplied by a coefficient of 0.45 (it shows carbon content in wood) and then the result was multiplied by a coefficient of 3.66 to convert carbon to carbon dioxide (this coefficient is presented in the method according to Bobylyov, 2001). As a result, it turned out that 1 ha of forest land deposits 0.7 tons of carbon dioxide. The same technique was used to calculate the amount of carbon deposited in meadow vegetation.

One hectare of meadow land annually sequestrates 0.45 tons of carbon. The amount of carbon sequestrated by meadows is multiplied by a coefficient of 3.66 to convert its mass to the mass of carbon dioxide. The result obtained is the mass value of carbon dioxide bound by 1 hectare of meadow, and is 1.6 tons. The price for 1 ton of carbon dioxide was accepted in the amount of US \$10 (Bobylyov, 2001). One hectare of forest land in the territory of the considered wetland systems binds carbon dioxide in the amount of $\$ 7$. One hectare of meadow land sequestrates $\$ 10.3$ carbon dioxide.

As a result of the calculations, the Teniz-Korgalzhyn system, the cost of which in the carbon market would be $\$ 4861630$ (Table 7 ), is of the greatest value in the service of carbon deposition and air purification. This is explained by the largest area with favorable conditions for the development of meadow and forest vegetation. Favorable conditions are due to climatic features of the region and uniform access of water, due to a whole system of large and small lakes remote from each other at small distances, occupying the Teniz-Korgalzhyn depression and its plains, plateaus and small hills. The Alakol-Sasykkol system is the second by area and by the amount of carbon sequestrated. 
The cost of absorbing carbon dioxide here is $\$$ 3.933.650. The area of local forest land is much smaller, since the conditions for their development are very different from the Teniz-Korgalzhyn system. Wetland occupies the Alakol-Sasykkol intermountain basin section between the mountain systems of Zhetysu Alatau and Tarbagatai. The location of the territory in the Alakol depression determines the special climatic regime of the region. First of all, changes in the hydrothermal regime are caused by inversion processes - the influence of mountains and the hollow effect. The entire lake and wetland ecosystem complex is formed in an arid desert climate. The least absorbing carbon dioxide is the territory of the Small Aral Sea and the Syr-DaryaRiver (Ospanova, 2012).

The area of the wetland is significantly inferior to the areas of the Teniz-Korgalzhyn or Alakol-Sasykkol systems, and its main part is represented by the water surface. It is worth noting that the obtained values are very approximate, since the calculations did not fully take into account the so-called carbon benefit, which is understood as the specificity of the age and structural composition of the stands and their full composition.

Table 7. Cost of carbon sequestration of Kazakhstan wetlands

(according to the Development Programs of the Regions of 2011-2018, and to the Decree of the Government of the Republic of Kazakhstan № 1140 dated September 4, 2001)

\begin{tabular}{|c|c|c|c|c|c|c|}
\hline \multirow{2}{*}{ Name of the object } & \multirow{2}{*}{$\begin{array}{l}\text { Meadows } \\
\text { area, ha }\end{array}$} & \multirow{2}{*}{$\begin{array}{l}\text { Area of } \\
\text { forest } \\
\text { lands, ha }\end{array}$} & \multicolumn{3}{|c|}{ Carbonsequestration, $\mathrm{t}$} & \multirow{2}{*}{$\begin{array}{c}\text { Carbonmarketvalue, } \\
\text { \$USA }\end{array}$} \\
\hline & & & Meadows & forests & total & \\
\hline $\begin{array}{c}\text { Tengiz- } \\
\text { Korgalzhinsksystem } \\
\text { of lakes }\end{array}$ & 268.719 & 62.261 & 442.580 & 43.583 & 486.163 & 4.861 .630 \\
\hline
\end{tabular}

\section{DISCUSSION}

The results of the study and calculations allow us to state that in the structure of the total economic cost of environmental services of all wetland landscapes of the study area, the main share is the cost of natural components - mainly flora and fauna, as well as the cost of agricultural products, carbon deposition, typical for regions with large areas of forest and meadow land. As can be seen, the ratio of the cost of the ecological functions of wetland landscapes for the considered model protected areas is different and depends on the hydroclimatic and landscape features of the territory, as well as on its biodiversity and degree of development. The results of the economic assessment of environmental services of protected areas provide an informative basis for solving a wide range of management tasks - determining the share of protected natural areas in the gross domestic product of Kazakhstan, the direction of development of protected areas, defining environmental management regimes, financing protected areas and timely adoption of necessary measures to preserve ecosystem biodiversity. Currently, Korgalzhyn Nature Reserve accepts organized collective and individual tourists. Tours and routes are organized over Korgalzhyn visiting center. One of the most important objective in the Korgalzhyn Nature Reserve is the Flamingo eco-route (155km).

The example of sightseeing tour: Visit to the monument of cultural heritage "Dudarai", the mausoleum "Batygay" mazar "Kanykey". This will introduce tourists to the legends and traditions of the region. On the lake Shopak can be observed different endangered bird species as cormorants, swans and curly pelican, the largest bird in the reserve, almost all summer large flocks of waterfowl and near-water birds gather on the Eseiskaya Spit. Further, on the Kendyktylake, you can see the pink flamingo-brand of the Korgalzhyn Reserve, large concentrations of waders, on Lake Saumalkol-can be observed the endangered species as duck-stifftail, swans, geese, and other. In the steppe 
Landscapes of the Teniz-Korgalzhyn Depression:

Evaluation of Ecosystem Functions and Opportunities for Tourism

can be seen badger, fox, wild boar, saigak and geese. On the Karazhar site can be organized a small rest and lunch, with the returning route.

\section{CONCLUSIONS}

The results of the study led to the following conclusions:

1. Among all the classes of animals considered in this paper, commercial and rare bird species are of the greatest economic value. Moreover, the total economic value of species varies significantly in wetlands. The maximum value of the indicator is characteristic of the Teniz-Korgalzhyn system of lakes, which is due to the large size of populations of rare bird species.

2. The Korgalzhyn Nature Reserve has the greatest tourist and recreational potential in the whole central Kazakhstan, which is explained by the recreational attractiveness of the territory and the favorable position and socio-economic situation. The main type of tourism and recreation is ecotourism, as scientific and educational value. The buffer zone of the Alakol reserve is characterized by the largest influx of tourists, but incomes remain low. This can be explained by the predominance of unorganized type of tourism.

3. Wetlands are characterized by features in the structure of agricultural land, which are characterized by a predominance of pasture in their composition, due to the aridity of the climate. In the Teniz-Korgalzhyn system of lakes, the share of pastures and tilled lands is approximately the same. Differences in the structure of agricultural land are caused by natural conditions (climatic conditions, topography, soil fertility, etc.). As a result of economic assessment of agricultural land, it was found that the highest values of the indicator are the lands of the Teniz-Korgalzhyn and Alakol-Sasykkol systems of lakes, which is explained by the large areas of pastures, hayfields and tilled lands. The smallest values are observed on the wetlands of the Naurzum system of lakes and the Small Aral Sea with the Syr-Darya River Delta.

4. The highest economic cost of filtration capacity is characteristic for the TenizKorgalzhyn and Alakol-Sasykkol systems of lakes.

5. The value of the carbon deposition service depends on the area of forest and meadow land, the productivity of vegetation. The productivity of forest and meadow vegetation of wetlands is at a very low level $(0.7 \mathrm{~m} 3 / \mathrm{ha})$. The area occupied by forests and meadows varies widely among wetlands, due to the natural conditions of their formation. The greatest value in the service of carbon deposition is characterized by the Teniz-Korgalzhyn lake system.

6. In the structure of the total economic cost of environmental services of all wetlands of Kazakhstan, the main share is the cost of natural resources, then follows the cost of agricultural land production. An exception is the Alakol-Sasykkol system of lakes, in which the share of the cost of natural resources and agricultural land production is almost the same. In the structure of the total economic value of the ecological services of the wetlands of the Naurzum system of lakes, a significant share of the cost of the services of carbon deposition is explained by the relatively large areas of forest and meadow lands. The Alakol-Sasykkol system of lakes is characterized by an increase in the percentage of filtering ability of wetlands.

7. The Korgalzhyn-Teniz depression have the high tourist potential, due the unique ecological system, variety of natural landscape, central location between important cities. It can develop the ecotourism activities and grow the income from the tourist and economically connected activities. At the same time it is important to keep the naturally protected areas and preserve the wild environment of the region. 


\section{REFERENCES}

Barbier, E.B., Acreman, M., \& Knowler, D. (1997). Economic Valuation of Wetlands. A guide for policy makers and planners. Ramsar Convention Bureau. Switzerland, Gland, 127 p.

Bobylyov, S.N. \& Tishkov, A.A. (1999) Economic assessment of biodiversity. Moscow, 112 p.

Bobylyov, S.N., Sidorenko, V.N., \& Luzhetskaya, N.V. (2001). The Economic Basics of Wetland Conservation. Moscow, 56 p.

Bragin, E.A., \& Bragina, T.M. (2002). Naurzum system of lakes. The most important wetlands of Northern Kazakhstan. Russian University. Moscow, 101-114 pp.

Brander, L.M., Florax, R.J.G.M., \& Vermaat, J.E. (2003). The Empirics of Wetland Valuation: A Comprehensive Summary and a Meta-Analysis of the Literature. Amsterdam, Institute for Environmental Studies (IVM), VrijeUniversiteit, 29 p.

Gozner, M. (2010). Tourism in the Territorial System Albac - Arieseni sistemul teritorial Albac and its impact on the environment. Analele Universităţii din Oradea, Fascicula Construcţii şi Instalaţii Hidroedilitare, vol. XIII - 2, Editura Universităţii din Oradea.

Gozner, M., Tătar, C.F., Stupariu, M. \& Măduța, M.F. (2017), Nature, Photography and Tourism in Bihor-Vlădeasa Mountains (Romania), GeoJournal of Tourism and Geosites, Year X, Volume 20, Oradea-Gdansk, Romania-Poland, Editura Universității din Oradea.

Ilies, D.C., Buhas, R., Ilies, M., Ilies, A., Gaceu, O., Pop, A.C., Marcu, F., Buhas, S.D., Gozner, M., \& Baias, S. (2018). Sport Activities and Leisure in Nature 2000 Protected Area - Red Valley, Romania. Journal of Environmental Protection and Ecology, 19, No 1, 367-372.

Ilieş, A., \& Wendt, J.A., (2015). Tourism geography. The basic of theory and application issues. [Geografia turystyczna. Podstawy teorii i zagadnienia aplikacyjne]. Wydawnictwo AWFiS, Gdańsk.

Kotlyarov, Y.A. (1978). Geography of Tourism and Recreation. Formation and Development of Territorial Recreation Complexes. M.: Mysl, p. 238.

Mazhitova, G.Z., Pashkov, S.V., \& Wendt J.A. (2018). Assessment of landscape-recreational capacity of north kazakhstan region. GeoJournal of Tourism and Geosites, 23 (3), 731-737.

Mironenko, N. S., \& Bochvarova, M. (1986). Recreational systems. Publishing house of Moscow University, Moscow, $136 \mathrm{p}$.

Mukhina, L.I. (1973). Principles and methods of technological assessment of natural complexes. M.: Nauka, p. 96.

Nazarova, T.V., Fomin, I.A., Dmitriev, P.S., Wendt, J.A., \& Janaleyeva, K.M. (2019). Landscape and limnological research of lake systems of the plain areas of the Northeastern borderlands of the Republic of Kazakhstan and assessment of their recreational capacity. GeoJournal of Tourism and Geosites, 25(2), 485-495 pp.

Ospanova, M.O. (2012) Biodiversity of wetlands in the outposts of the Syr-Darya River. Almaty, 65 p.

Preobrazhenskiy V.S. Antipova A.V., Vedenina Yu.A., \& Danilova N.A. (1975). The theoretical basis of recreational geography. Exec. edit. M.: Nauka, p 224.

Yashchenko, R.V. (2006). Reserves of Central Asia and Kazakhstan. Materials of the IUCN project "Evaluation of the Management Effectiveness of Central Asia and Kazakhstan Reserves". Vol. 1. Tethys. Almaty, 352 p.

Zavadskaya, A.V., Nikolaeva, E.A., Sazhina, V.A., Shpilenok, T.I., Shuvalova, O.A. (2017). Economic assessment of natural resources and ecosystem services of the Kronotsky Reserve and the South Kamchatka Reserve. Kamchatpress, Petropavlovsk-Kamchatsky, 244 p.

*** Atlas of Wetlands of Kazakhstan. 2009. Astana. 84 p.

*** Millennium of geo system Assessment (2005) World Resources Institute, Washington, $69 \mathrm{p}$.

*** Syrdarya Region Development Program until 2020. 2012. [Electronic resource: http://kostanay.gov.kz/ programmy-razvitiya-territoriy (accessed on September 22, 2013).]

*** The development program of the East Kazakhstan region until 2020. 2012. [Electronic resource: http://kostanay.gov.kz/programmy-razvitiya-territoriy (accessed on September 22, 2013).]

*** The globally significant wetlands of Kazakhstan. 2007. In 3 volumes. Astana: Printing House Complex. T. 1.264 page; T. 2.271 page; T. 3.27 page.

*** The official website of the Committee for Forestry and Wildlife of the Ministry of Agriculture of the Republic of Kazakhstan. [Electronic resource: http://www.fhc.kz (accessed in January 15, 2014).]

Submitted:

26.08.2019
Revised:

01.11.2019
Accepted and published online

04.11.2019 